\title{
Rapid naming: The Importance of Different Reading and Spelling Dimensions
}

\section{Mominación rápida: la importancia de diferentes dimensiones de lectura y ortografía nomeação rápida: a importância de diferentes dimensões de leitura e ortografia}

\author{
Cristina P. Albuquerque* \\ ${ }^{*}$ University of Coimbra, Coimbra, Portugal
}

Doi: http://dx.doi.org/10.12804/revistas.urosario.edu.co/ap1/a.3715

\section{Abstract}

This research extends the empirical evidence regarding the influence of rapid naming on the acquisition of reading and spelling of European Portuguese in third and fourth grade children. In reading, it addresses different dimensions (accuracy and fluency) and materials (words, pseudowords, and text) and it controls the influence of phonological awareness. In spelling, it addresses the accuracy and the fluency in the codification of words and pseudowords and it controls the influence of phonological awareness and handwriting fluency. In reading, rapid naming explained higher variance percentages in fluency than in accuracy. The main effect was registered on text reading fluency by a RAN digit test. In spelling, rapid naming predicted a small, but significant, percentage of word spelling fluency.

Keywords: Rapid naming; reading; spelling; Portuguese.

\section{Resumen}

Esta investigación amplía la evidencia empírica relativa a la influencia de la nominación rápida en el aprendizaje de la lectura y escritura del portugués europeo en niños de tercero y cuarto de primaria. En la lectura, tiene en cuenta distintas dimensiones (precisión y fluidez) y materiales (palabras, pseudopalabras y texto) y controla la influencia de la consciencia fonológica. En la escritura, tiene en cuenta la precisión y la fluidez en la codificación de palabras y pseudopalabras y controla la influencia de la consciencia fonológica y de la fluidez caligráfica. En la lectura, tests RAN (uno de colores y uno de dígitos) $\mathrm{y}$ un test RAS (formas y colores) explicaban porcentajes más elevados de varianza en la fluidez que en la precisión. Lo principal ha sido registrado en la fluidez en la lectura de un texto por el test RAN de dígitos. En la escritura, la nominación rápida predice un pequeño, más significativo, porcentaje de fluidez en la escritura de palabras.

Palabras clave: nominación rápida; lectura; escritura; portugués.

\section{Resumo}

Esta pesquisa amplia a evidência empírica relativa à influência da nomeação rápida na aprendizagem da

* Cristina P. Albuquerque, Faculty of Psychology and Educational Sciences, University of Coimbra, Coimbra, Portugal.

Correspondence concerning this article should be addressed to Cristina P. Albuquerque, Rua do Colégio Novo - Apartado 6153, 3001-802 Coimbra, Portugal. Phone: 239851450/239851456. E-mail: calbuquerque@fpce.uc.pt

Cómo citar este artículo: Albuquerque, C. P. (2017). Rapid Naming: The Importance of Different Reading and Spelling Dimensions. Avances en Psicología Latinoamericana, 35(1), 43-60. doi: http://dx.doi.org/10.12804/revistas.urosario.edu.co/ ap1/a.3715 
leitura e escrita do Português Europeu em crianças de terceiro e quarto ano de escolaridade. Na leitura, tem em conta diferentes dimensões (precisão e fluidez) e materiais (palavras, pseudo-palavras e texto) e controla a influência da consciência fonológica. $\mathrm{Na}$ escrita, tem em conta a precisão e a fluidez na codificação de palavras e pseudo-palavras e controla a influência da consciência fonológica e da fluidez caligráfica. Na leitura, testes RAN (um de cores e um de dígitos) e um teste RAS (formas e cores) explicavam porcentagens mais elevadas de variação na fluidez que na precisão. $O$ efeito principal tem sido registrado na fluidez na leitura de um texto pelo teste RAN de dígitos. Na escrita, a nomeação rápida prediz uma pequena, mas significativa, percentagem da fluidez na escrita de palavras.

Palavras-chave: nomeação rápida; leitura; escrita; português.

\section{Introduction}

During the last three decades, rapid automatic naming has emerged as an important predictor, concurrent and longitudinal, of reading. Its role was initially studied in the English language (Bowers \& Swanson, 1991; Manis, Doi, \& Bhadha, 2000; Savage et al., 2005), which is considered to have an inconsistent or deep orthography due to the reduced predictability of the matching between grapheme and phonemes. Nevertheless, the analysis of the influence of rapid naming quickly extended to other languages, both alphabetic and non-alphabetic (e.g., Chinese - Ding, Richman, Yang, \& Guo, 2010; Georgiou et al., 2011), as demonstrated by the list of 18 languages compiled by Norton and Wolf (2012).

In this context, there are studies on the Portuguese language, in both its European Portuguese variant (Albuquerque, 2012; Araújo, Pacheco, Faísca, \& Petersson, 2010; Sucena, Castro, \& Seymour, 2009; Ziegler et al., 2010) and its Brazilian Portuguese variant (Cardoso-Martins, Corrêa, \& Magalhães, 2010; Justi \& Roazzi, 2012; Smythe et al., 2008). However, it should be emphasised that the two variants have important differences in terms of pronunciation, which has an effect on the correspondences between the oral and written languages and therefore does not allow the direct comparison of the data concerning them. In the particular case of European Portuguese, to which the present investigation refers, it is noted that this is a language that has been considered intermediate in terms of orthographic depth and is not as shallow as some other languages (e.g., Finnish, Greek, Italian) or as deep as English and French (Borgwaldt, Hellwig, \& De Groot, 2005; Seymour, Aro, \& Erskine, 2003). Based on these general remarks, we can sum up the empirical evidence on the role of rapid naming in reading in European Portuguese, stating that it is restricted and that it relates both to children with dyslexia (Araújo et al., 2010; Sucena et al., 2009) and to normally achieving children (Albuquerque, 2012; Ziegler et al., 2010). In the latter, it demonstrates that rapid naming contributes to reading fluency in children in first and second grade (Albuquerque, 2012; Ziegler et al., 2010).

Although many investigations have studied the role of rapid naming, many questions remain unanswered. Thus, there are studies that refute the influence of rapid naming on reading (Cardoso-Martins \& Pennington, 2004; Puolakanaho et al., 2008; Savage et al., 2005) or that attribute a very modest relevance to it (Hammill, Mather, Allen, \& Roberts, 2002) or that find it has a variable relevance according age or grade level. In the latter case, it is noted either that the relationship is more important at the beginning of elementary school (Cardoso-Martins \& Pennington, 2004; de Jong \& van der Leij, 2002; Sunseth \& Bowers, 2002) or that the relationship is more important at the end of or after fourth grade (Nikolopoulos, Goulandris, Hulme, \& Snowling, 2006; Protopapas, Altani, \& Georgiou, 2013; Vaessen \& Blomert, 2010; van den Bos, Zijlstra, \& Spelberg, 2002). The inconsistency of these results may derive from the languages that have been studied (English, Dutch, Greek), from 
the different reading dimensions that have been addressed (accuracy in decoding; reading speed; reading accuracy and speed) and/or from the different reading materials that have been used. As we shall focus throughout this study, these may be relevant differences. Nevertheless, the studies that addressed reading fluency, and that assessed it as accuracy and speed (Vaessen \& Blomert, 2010; van den Bos et al., 2002), found an increase in its relation with rapid naming as participants got older.

Another open question, closely related to the previous one, concerns the dimensions of reading that have been analysed because fluency has been privileged, and accuracy in decoding and reading comprehension have been neglected. In turn, fluency has been measured as accuracy and speed, i.e., in terms of the number of words correctly read per unit of time (e.g., second-Araújo et al., 2010and minute-Babayiğit \& Stainthorp, 2010, 2011; Papadopoulos, Georgiou, \& Kendeou, 2009; Puolakanaho et al., 2008; van den Bos et al., 2002), as speed, i.e., in terms of the number of words or syllables read per unit of time (e.g., secondZiegler et al., 2010 - and minute-Di Filippo et al., 2005; Ding et al., 2010; Moll, Fussenegger, Willburger, \& Landerl, 2009) or in terms of total reading time (Nikolopoulos et al., 2006). None of these measures reflects the complexity of the conceptions of fluency in reading, which involve decoding accuracy, automaticity in the recognition of words and expressive or prosodic reading (Kuhn, Schwanenflugel, \& Meisinger, 2010). However, fluency in reading is better viewed in terms of accuracy and speed (Kuhn et al., 2010) than solely in terms of speed. In addition, the operationalisation in terms of speed is likely to influence correlations with rapid naming because the latter also requires processing speed.

As far as writing is concerned, the role of rapid naming has been considerably less investigated than in reading. Nonetheless, there has been a slight increase in recent years, as is evident in studies of languages other than English (for example:
German-Moll et al., 2009; Chinese-Ding et al., 2010; Yan et al., 2012; Dutch-Vaessen, Gerretsen, \& Blomert, 2009; Turkish-Babayiğit \& Stainthorp, 2010, 2011) as well as in studies that analysed and compared several languages simultaneously (Georgiou et al., 2011; Smythe et al., 2008). Moreover, the emphasis has been on spelling and has indicated a modest influence of rapid naming on spelling accuracy (Babayiğit \& Stainthorp, 2011; Ding et al., 2010; Georgiou et al., 2011; Justi \& Roazzi, 2012; Moll et al., 2009; Savage et al., 2005; Savage, Pillay, \& Melidona, 2008; Stainthorp, Powell, \& Stuart, 2013), although the results do not appear to be entirely consistent with themselves when comparing several languages (Smythe et al., 2008) or even when comparing research carried out within the same language (for example, Landerl \& Wimmer, 2008; Moll et al., 2009).

In turn, spelling accuracy has been measured in terms of the number of dictated words correctly spelled (for example, Babayiğit \& Stainthorp, 2010, 2011; Cardoso-Martins \& Pennington, 2004; Georgiou et al., 2011; Smythe et al., 2008), and no research has been found that has focused on accurate and rapid spelling, i.e., on the number of dictated words correctly spelled in a given time interval. However, as children progress in schooling, it is expected that they are able to evoke the orthographic representations more quickly, with less effort and less consciously; that is, it is expected that spelling becomes automatic instead of being laboriously constructed from phonological, spelling and/or morphological information (Berninger et al., 2006; Yan et al., 2012). As shown by Berninger et al. (2006), elementary school children show evidence of fast mapping of oral/aural word forms onto written word forms; this fast mapping is automatic and explains unique variance in spelling achievement over and beyond orthographic and phonological coding abilities. Similarly, it is also expected that handwriting - which, together with spelling, represents transcription skills-will become progressively more automatic (Berninger 
et al., 2006; Graham, Berninger, Abbott, Abbott, \& Whitaker, 1997). In this regard, it should be noted that rapid naming has been viewed as evaluating the automaticity with which basic or lower processes are carried out; i.e., it indicates the extent to which such processes become faster and autonomous and require reduced cognitive resources (Norton \& Wolf, 2012). Automaticity would be more important than lexical access, phonological processes or any other of the various components that are inherent to rapid naming, thus underlining the relevance of the analysis of rapid naming's relationship with spelling and handwriting.

Handwriting and spelling must be coordinated for transcription of oral language into written language, and several studies have shown that handwriting skills influence spelling performance (Fayol \& Miret, 2005; Graham et al., 1997). Nevertheless, handwriting fluency has not been controlled in the analyses of the relationships between rapid naming and spelling.

Given that there are many types of tasks or tests of rapid naming, the distinction between RAN ( $R a$ pid Automatic Naming) and RAS tests (Rapid Alternating Stimulus) should also be addressed: RAN tests contain a single type of stimuli, which can be alphanumeric or non-alphanumeric stimuli; RAS tests contain stimuli belonging to different semantic categories (e.g., shapes and colours). Indeed, RAN tests have been considered simpler, more automatic and less demanding in terms of the cognitive and linguistic processes involved, whereas RAS tests would be more demanding in terms of attention, memory access, executive functions, semantic processing and phonological processing (Närhi et al., 2005; Wiig, Zureich, \& Chan, 2000). It has also been found that RAN tests with alphanumeric stimuli present, when compared with RAN tests with non-alphanumeric stimuli, more important associations with accuracy in reading (Manis et al., 2000; Savage et al., 2008), with accuracy and speed in reading (Cardoso-Martins \& Pennington, 2004; Georgiou, Parrila, \& Liao, 2008; van den
Bos et al., 2002) and with accuracy in spelling (Cardoso-Martins \& Pennington, 2004; Savage et al., 2008). Therefore, there is a full advantage in comparing the different types of instruments of rapid naming assessment.

\section{Present Study}

The present study aims, first, to expand on the empirical evidence regarding the influence of rapid naming in the learning of reading and spelling in European Portuguese. The available empirical evidence, as we have already noted, is restricted and, in the case of normally achieving children, is limited to the first and second grades. This study evaluates children from the third and fourth grades, because important progresses in reading accuracy and speed have been registered in these grades (Vaessen \& Blomert, 2010) or between the age levels of 8 and 10-year-olds (van den Bos et al., 2002). In European Portuguese, Carvalho (2010) also noted an appreciable improvement in reading fluency after grade 2. Besides, the association between rapid naming and reading fluency may increase through the elementary grades (van den Bos et al., 2002) and particularly in grades 3 or 4 (Vaessen \& Blomert, 2010). Important progresses are also expected to occur in spelling and handwriting in these grades (Berninger et al., 2006; Graham et al., 2007), since according to Fayol and Miret (2005), children only acquire some domain in these skills in and after third grade.

It is also important to study European Portuguese because it has an orthography that has been classified as intermediate in terms of letter-phoneme correspondence (Borgwaldt et al., 2005; Seymour et al., 2003). As it has been suggested that the influence of rapid naming may vary according to this parameter (Di Filippo et al., 2005; van den Bos et al., 2002), it is relevant to analyse languages ambiguous in this regard, as European Portuguese.

Furthermore, this study aims to analyse the relationship of rapid naming with different dimensions 
of reading and spelling and with different types of materials. Thus, second, and with regard to reading, it intends to circumscribe the relationships that rapid naming establishes with accuracy and fluency in the decoding of words, pseudowords, and of a text as well as to analyse its predictive power after the influence of phonological awareness has been controlled. We anticipate more important associations of rapid naming with fluency in reading and the existence of a specific influence at this level.

Third, and as far as spelling is concerned, we intend to examine the effect of rapid naming on the level of the coding of words and pseudowords, particularly in terms of the respective accuracy and fluency. Similar to reading, we raise the hypothesis that rapid naming has a closer relationship with spelling fluency. Regarding spelling, we also intend to circumscribe and confirm the predictive power of rapid naming once the influence of phonological awareness and handwriting has been controlled.

Fourth, this study intends to analyse the relationships between rapid naming and fluency in handwriting, and we expect, due to the automaticity and processing speed inherent to both, that there will be significant relationships between them.

Finally, we intend to draw comparisons between reading and spelling and, within each between a RAN colour test, a RAN digit test, and a RAS test of naming shapes and colours. In this regard, we formulate the hypothesis that a RAN digit test is more associated with reading and writing than a RAN colour test or a RAS test of shapes and colours.

\section{Method}

\section{Participants}

The sample consisted of 53 children from the third grade and 52 from the fourth. Of the third graders, 25 were boys and 28 were girls and their mean age was $8(M=8.28 ;$ S.D. $=0.45)$. Of the fourth graders, 27 were boys and 25 were girls, and their mean age was 9 years $(M=9.21 ; S . D .=0.41)$. All children attended state elementary schools in the district of Coimbra, were native European Portuguese speakers and did not present special needs. Parents gave informed consent for their children's participation.

\section{Instruments}

Rapid Naming Tests. These were comprised of two RAN tests (colours and digits) and one RAS test (shapes and colours) that are part of the Neuropsychological Assessment Battery of Coimbra (BANC; Simões et al., 2008). In each test, the child was asked to name, as quickly as possible, 50 visual stimuli presented randomly on a card. All tests also include 10 practice stimuli presented on a different card.

The digits are 2, 4, 6, 7 and 9, and the colours are blue, yellow, red, black, and green. The RAS test of shapes and colours has four shapes (circle, rectangle, square and triangle) with four different colours (yellow, red, black and green).

The score used in this study was the time it took the child to name all 50 stimuli. The reliability was investigated on the BANC normative sample using the test-retest method. The values obtained, in a time interval of approximately 27 days, were .82 in the colour naming test, .78 in the digit naming test, and .90 in the shape and colour naming test.

Phonemic Awareness Tests. These tests included an Elision test and a Substitution test that are also part of the Neuropsychological Assessment Battery of Coimbra (BANC; Simões et al., 2008). Each of these tests contains 19 items and 2 example items. The Elision test assesses the extent to which the child can say familiar words after dropping out a designated phoneme. The words have four to seven phonemes and are mainly dissyllabic (fourteen are dissyllabic). The phonemes to be deleted are consonants in either word-initial (five words), word-final (two words) or word-medial positions (twelve words). 
The Substitution test assesses the extent to which the child can say familiar words after having replaced one (18 items) or more phonemes ( 1 item) with others. The words have four to six phonemes and are dissyllabic, except one that is monosyllabic. The phonemes to be replaced are consonants in either word-initial (nine words), word-final (two words) or word-medial positions (eight words).

The answers are scored with 0 or 1 points. The values of internal consistency reliability in the BANC normative sample were .91 on the Elision test and .90 on the Substitution test. The test-retest coefficients (mean time interval of 27 days) were .83 in the Elision test and .85 in the Substitution test.

Word Reading. This task includes a list of 38 words, of which 20 are orthographically irregular words and 18 are orthographically regular words. A word was considered irregular if its letter sequence contained ambiguous pronunciations (e.g., qu/gu, which can be read $[\mathrm{k} / \mathrm{g}]$ or $[\mathrm{kw} / \mathrm{gw}])$.

Because the Portuguese lexicon is mainly multisyllabic, the list contains only words with two or more syllables ( $50 \%$ are 3 -syllable words). The words vary in frequency according to the Corlex data base (Bacelar do Nascimento et al., 2005), but the majority of the words $(65.8 \%)$ have a high or intermediate frequency.

The words were presented as a list and a stopwatch was used to time the task. Two scores were derived: the total number of words correctly read and the number of words correctly read divided by the reading time. Each word correctly read received 1 point (internal consistency: alpha $=.90$ ).

Pseudoword Reading. A list of 20 pseudowords with 2-syllables was extracted from the Portuguese Battery PAL-PORT (Festas et al., 2006). Ten pseudowords present a univocal relationship between the letters and the phonemes (e.g., flaco ['flaku]). In the other 10 pseudowords, the sequence of the letters conditions reading, as shown by the following examples: the letter $<\mathrm{c}>$ before $<\mathrm{i}>$ or $<\mathrm{e}>$ is read [s] (e.g., ciro ['siru]), but in any other context, it is $\operatorname{read}[\mathrm{k}]$; the letter $<\mathrm{g}>$ before $<\mathrm{i}>$ or $<\mathrm{e}>$ is always read [3] (e.g., gito ['zitu]).

Two scores were derived: the total number of pseudowords correctly read and the number of pseudowords correctly read divided by the reading time. Each pseudoword correctly read received 1 point (internal consistency: alpha $=.78$ ).

Text Reading. This was assessed through the test "O Rei" (Carvalho, 2010), which has norms for Portuguese children aged 7 to 12 . It consists of reading a text with a total of 281 words in 3 minutes (or fewer if the child is able to read it). This test has adequate psychometric properties, as evidenced, for instance, in the high values of test-retest reliability (e.g., .85 for time and .94 for the number of words correctly read).

Two scores were calculated corresponding to the ones previously mentioned for word and pseudoword reading.

Word Spelling. In this task, 38 words were dictated one by one to each child. Eighteen words were regular, and 20 were irregular, the latter of which was comprised of the following situations: the mute consonant h; the phoneme [3], which can be spelled as $\langle\mathrm{j}>$ or $\langle\mathrm{g}>$ before $<\mathrm{i}>$ or $\langle\mathrm{e}>$; the phoneme [J], which can be spelled as $<\mathrm{x}>$ or $<\mathrm{ch}>$; the phoneme [s], which can be spelled as $\langle\mathrm{c}\rangle$, as $<\mathrm{s}>$, as $<$ ss $>$, as $<$ ç $>$ and as $<\mathrm{x}>$; and the phoneme [z], which can be represented as $\langle\mathrm{S}\rangle$, as $\langle\mathrm{z}>$ or as $\langle\mathrm{x}\rangle$. All the words are multisyllabic, predominantly dissyllabic and trisyllabic $(60.5 \%)$ and of high or intermediate frequency $(65.8 \%$; Bacelar do Nascimento et al., 2005).

Each word correctly spelled received 1 point (internal consistency: alpha $=.88$ ) and the time needed to spell all words was registered. In addition, the total number of words correctly spelled was divided by the spelling time.

Pseudoword Spelling. This task is composed of a list of 20 pseudowords with 2-syllables that was selected from the Portuguese Battery PAL-PORT (Festas et al., 2006). Each pseudoword was dictated one by one to each child. There are 10 pseudowords 
in which the phoneme always corresponds to a single letter (e.g., trimo ['trimu]). There are also 10 pseudowords whose correct spelling requires the knowledge of specific rules, as illustrated by the following examples: the sequence [ki] or [ke] can only be spelled by means of $<$ qui $>$ or $<$ que $>$; the tonic vowels $[\mathrm{a}],[\varepsilon]$ and $[0]$ require a stress mark at the end of the word.

Each pseudoword correctly spelled received 1 point (internal consistency: alpha $=.81$ ). Two scores were calculated, corresponding to the ones mentioned regarding word spelling.

Alphabet Task. The children were asked to write down all the letters of the alphabet as quickly as possible and without making any mistakes in the period of 1 minute (Berninger \& Rutberg, 1992; Olive, Favart, Beauvais, \& Beauvais, 2009). The instructions told the children to write the lowercase letters one after another, and also that if they finished writing down all the letters in less than 1 minute, then they had to start writing down the alphabet again. The score was the number of letters correctly written in the period of 1 minute.

\section{Procedure}

Children performed all the assessment tasks individually and in a quiet place in the school building. The instruments were administered in the following order: writing (word spelling and pseudoword spelling), rapid naming (RAN colours, RAN digits and RAS shapes and colours), alphabet task, phonological awareness (Elision and Substitution) and reading (word reading, pseudoword reading and text reading).

\section{Results}

\section{Preliminary Analysis}

Table 1 shows a summary of the raw scores obtained. A composite phonological awareness score was created by transforming the raw scores of the Elision and Substitution tests into $\mathrm{z}$ scores and then summing them. This option rests on the assumption that single indicators of phoneme awareness may be subject to considerable measurement error and instability.

Table 1

Mean, standard deviation and range for the various measures

\begin{tabular}{|c|c|c|c|c|c|c|}
\hline & \multicolumn{3}{|c|}{$3^{\text {rd }}$ Grade } & \multicolumn{3}{|c|}{$4^{\text {th }}$ Grade } \\
\hline & \multicolumn{3}{|c|}{$(n=53)$} & \multicolumn{3}{|c|}{$(n=52)$} \\
\hline & $\mathrm{M}$ & SD & $\begin{array}{c}\text { Min-Max- P. } \\
\text { Max }^{\mathrm{a}} .\end{array}$ & M & SD & $\begin{array}{c}\text { Min-Max- P } \\
\text { Max. }^{\text {a }}\end{array}$ \\
\hline RN Color Time ${ }^{b}$ & 46.91 & 9.83 & $29-81$ & 41.12 & 8.56 & $29-59$ \\
\hline RN Digit Time ${ }^{b}$ & 28.42 & 6.27 & $17-48$ & 25.48 & 4.50 & $16-36$ \\
\hline RN Shape/Color Time ${ }^{b}$ & 119.77 & 28.98 & $69-210$ & 99.88 & 20.47 & $70-157$ \\
\hline PA Elision & 14.74 & 3.57 & 4-18-19 & 16.04 & 2.83 & $6-19-19$ \\
\hline PA Substitution & 14.15 & 3.29 & $1-18-19$ & 15.88 & 2.73 & $8-19-19$ \\
\hline Word Reading Total Correct & 31.66 & 2.99 & $21-36-38$ & 33.13 & 2.21 & $28-37-38$ \\
\hline Word Reading Total Correct/Time & .40 & .17 & $.12-1.03$ & .49 & .18 & $.2-1$ \\
\hline Pseudoword Reading Total Correct & 17.32 & 2.09 & $10-20-20$ & 18.17 & 1.67 & $14-20-20$ \\
\hline Pseudoword Reading Total $C^{c}$./Time & .48 & .17 & $.18-.91$ & .57 & .22 & $.21-1.27$ \\
\hline
\end{tabular}




\begin{tabular}{lcccccc}
\hline & \multicolumn{3}{c}{$3^{\text {rd }}$ Grade } & \multicolumn{2}{c}{$4^{\text {th }}$ Grade } \\
\cline { 2 - 7 } & \multicolumn{3}{c}{$(n=53)$} & & $(n=52)$ \\
\cline { 2 - 7 } & $\mathrm{M}$ & $\mathrm{SD}$ & $\begin{array}{c}\text { Min-Max- P. } \\
\text { Max }\end{array}$ & M & SD & $\begin{array}{c}\text { Min-Max- P. } \\
\text { Max. }^{\text {a }}\end{array}$ \\
\hline Text Reading Total Words Correct & 248.51 & 38.23 & $119-281-281$ & 268.90 & 20.27 & $179-281-281$ \\
\hline Text Reading Total Words C $/$ Time & 1.55 & .42 & $.66-2.77$ & 1.86 & .43 & $.84-2.75$ \\
\hline Alphabet - Letters Correct & 35.19 & 12.32 & $9-67$ & 42.40 & 13.49 & $18-75$ \\
\hline Word Spelling Total Correct & 23.08 & 4.40 & $15-33-38$ & 25.48 & 4.26 & $17-37-38$ \\
\hline Word Spelling Total Correct/Time & .08 & .02 & $.4-.13$ & .10 & .03 & $.06-.19$ \\
\hline Pseudoword Spelling Total Correct & 13.58 & 3.14 & $0-18-20$ & 14.65 & 2.28 & $9-20-20$ \\
\hline Pseudoword Spelling Total Correct/Time & .11 & .04 & $0-.20$ & .15 & .04 & $.07-.23$ \\
\hline
\end{tabular}

${ }^{a}$ Min-Max- P. Max = Minimum, Maximum and Possible Maximum (when there is one). ${ }^{b}$ In seconds ${ }^{c}$ Correct

There were between 1-5 outliers, in several variables, which were Winsorised (Wilcox, 2005). A slight negative skewness was noticed in two variables related to pseudowords and text reading accuracy, and a slight positive skewness was noticed on three other variables (RAS of shapes and colours; ratio words correctly read/reading time; ratio words correctly spelled/spelling time). Base
10 logarithmic transformations improved the distributions, but did not change the results in any noteworthy way.

\section{Correlations}

The correlations between the variables are presented in table 2 . Regarding reading, there are

Table 2

Correlations between measures

\begin{tabular}{|c|c|c|c|c|c|c|c|c|c|c|c|c|c|c|c|}
\hline & 1 & 2 & 3 & 4 & 5 & 6 & 7 & 8 & 9 & 10 & 11 & 12 & 13 & 14 & 15 \\
\hline 1. RN Color & - & $.40 * *$ & $.66^{* *}$ & -.09 & $-.32 *$ & $-.33 *$ & .02 & $-.29 *$ & -.16 & $-.43 * *$ & -.03 & -.24 & $-.31 *$ & .01 & -.19 \\
\hline 2. RN Digit & $.54 * *$ & - & $.37 * *$ & $-.30 *$ & $-.30 *$ & $-.52 * *$ & $-.40 * *$ & $-.52 * *$ & $-.38 * *$ & $-.58 * *$ & $-.51 * *$ & -.15 & $-.35^{*}$ & -.01 & -.13 \\
\hline 3. RN Shape/Color & $.48^{* *}$ & $.51 * *$ & - & -.07 & $-.33 *$ & $.34 *$ & .03 & -.20 & -.23 & $-.36^{* *}$ & -.12 & -.23 & $-.31 *$ & .14 & -.11 \\
\hline 4. PA composite & .09 & $-.34 *$ & -.16 & - & $.61 * *$ & $.42 * *$ & $.42 * *$ & $.38^{* *}$ & .10 & $.37 * *$ & $.40 * *$ & $.44 * *$ & $.29 *$ & $.34 *$ & .20 \\
\hline $\begin{array}{l}\text { 5.Word Reading } \\
\text { Total Correct }\end{array}$ & -.14 & $-.52 * *$ & -.24 & $.70 * *$ & - & $-.66^{* *}$ & $.32 * *$ & $.48 * *$ & .07 & $.55^{* *}$ & .15 & $.63 * *$ & $.45^{* *}$ & $.27 *$ & $.29 *$ \\
\hline $\begin{array}{l}\text { 6. Word Reading } \\
\text { Total Correct/Time }\end{array}$ & $-.35^{*}$ & $-.60^{* *}$ & $-.36^{* *}$ & $.38 * *$ & $.67 * *$ & - & .27 & $.74 * *$ &. $.34 *$ & $.83^{* *}$ & $.31 *$ & $.59 * *$ & $.63^{* *}$ & .01 & .27 \\
\hline $\begin{array}{l}\text { 7. Pseudoword } \\
\text { Reading T. } C^{a} \text {. }\end{array}$ & -.11 & $-.40 * *$ & $-.38 * *$ & $.58 * *$ & $.64 * *$ & $.46^{* *}$ & - & $.58 * *$ & .07 & $.30^{*}$ & .26 & .18 & -.02 & .20 & -02 \\
\hline $\begin{array}{l}\text { 8. Pseudoword } \\
\text { Reading T.C }{ }^{a} . / \\
\text { Time }\end{array}$ & $-.28^{*}$ & $-.59 * *$ & $-.37 * *$ & $.44 * *$ & $.68 * *$ & $.74 * *$ & $.61 * *$ & - & .25 & $.75^{* *}$ & $.42 * *$ & $.48^{* *}$ & $.55^{* *}$ & -.01 & .18 \\
\hline $\begin{array}{l}\text { 9. Text Reading } \mathrm{T} \text {. } \\
\text { Words Correct }\end{array}$ & $-.39 * *$ & $-.67 * *$ & $-.52 * *$ & $.38 * *$ & $.64 * *$ & $.65^{* *}$ & $.50 * *$ & $.63 * *$ & - & $-.49 * *$ & .14 & .22 & .17 & .05 & .06 \\
\hline
\end{tabular}




\begin{tabular}{|c|c|c|c|c|c|c|c|c|c|c|c|c|c|c|c|}
\hline & 1 & 2 & 3 & 4 & 5 & 6 & 7 & 8 & 9 & 10 & 11 & 12 & 13 & 14 & 15 \\
\hline $\begin{array}{l}\text { 10. Text Reading } \\
\text { T. W. C } C^{b} / \text { Time }\end{array}$ & $-.44 * *$ & $-.67 * *$ & $-.48 * *$ & $.32 *$ & $.65^{* *}$ & $.70 * *$ & $.48 * *$ & $.77 * *$ & $.84 * *$ & - & $.33^{*}$ & $.66^{* *}$ & $.70 * *$ & .02 & .23 \\
\hline $\begin{array}{l}\text { 11. Alphabet - Let- } \\
\text { ters Correct }\end{array}$ & $-.28 *$ & $-.56^{* *}$ & $-.28 *$ & $.31^{*}$ & $.45^{* *}$ & $.50 * *$ & .25 & $.46^{* *}$ & $.52 * *$ & $.50 * *$ & - & -.00 & $.32 *$ & .08 & $.32 *$ \\
\hline $\begin{array}{l}\text { 12. Word Spelling } \\
\text { Total Correct }\end{array}$ & -.22 & $-.48 * *$ & $-.36^{* *}$ & $.39 * *$ & $.59 * *$ & $.58 * *$ & $.48 * *$ & $.50 * *$ & $.65^{* *}$ & $.68 * *$ & $.48 * *$ & - & $.72 * *$ & .24 & .20 \\
\hline $\begin{array}{l}\text { 13. Word Spelling } \\
\text { T. C } \text { a }_{\text {Time }}\end{array}$ & $-.40 * *$ & $-.56^{* *}$ & $-.42 * *$ & $.34 *$ & $.52 * *$ & $.57 * *$ & $.39 * *$ & $.56^{* *}$ & $.66^{* *}$ & $.75 * *$ & $.66^{* *}$ & $.68 * *$ & - & -.01 & $.47 * *$ \\
\hline $\begin{array}{l}\text { 14. Pseudoword } \\
\text { Spelling T. } C^{a} \text {. }\end{array}$ & -.16 & $-.37 * *$ & $-.33 *$ & $.49 * *$ & $.53 * *$ & $.39 * *$ & $.53 * *$ & $.41^{* *}$ & $.46^{* *}$ & $.46^{* *}$ & $.38 * *$ & $.60 * *$ & $.38 * *$ & - & $.60 * *$ \\
\hline $\begin{array}{l}\text { 15. Pseudoword S. } \\
\text { T. C. } / \text { Time }\end{array}$ & $-.28 *$ & $-.37 * *$ & $-.35 * *$ & $.36^{* *}$ & $.51 * *$ & $.49 * *$ & $.42 * *$ & $.53 * *$ & $.41 * *$ & $.57 * *$ & $.55^{* *}$ & $.48^{* *}$ & $.69 * *$ & $.67 * *$ & - \\
\hline
\end{tabular}

Note: Below diagonal $=3^{\text {rd }}$ Grade; Above diagonal $=4^{\text {th }}$ Grade.

${ }^{\mathrm{a}}$ T. C. $=$ Total Correct ${ }^{\mathrm{b}} \mathrm{T}$. W. C $=$ Total Words Correct ${ }^{\mathrm{c}}$ Pseudoword S. T. C. $=$ Pseudoword Spelling Total Correct

$* \mathrm{p}<.05 * * \mathrm{p}<.01$

moderate correlations between the measures of rapid naming and all of the reading materials under analysis (words, pseudowords, and text; values are comprised, predominantly, between .30 and .60). Except for minor exceptions, the correlations are significant with respect to any of the reading dimensions analysed, although they are more important in the case of fluency (ratio words or pseudowords correctly read/reading time). Phonological awareness is related primarily with accuracy in reading.

Concerning spelling, its relationships with the rapid naming tests are inconsistent and more modest than those registered in the area of reading (values are comprised, predominantly, between .20 and .50). Nonetheless, they are more important in relation to the spelling of words than pseudowords, and within the former in relation to spelling fluency (ratio words correctly spelled/spelling time; correlations range from a minimum of -.31 in the fourth grade and a maximum of -.56 in the third grade). Phonological awareness registers again, the higher correlation values with spelling accuracy.

In turn, handwriting fluency, measured in terms of the number of alphabet letters correctly written within 1 minute, presents a significant relationship both in third and fourth grades only with the RAN digit test. Within the scope of spelling, handwriting fluency shows a more important relationship with fluency.

The relationships between the different tests of rapid naming are moderate and range from a minimum of .37 between the tests of shapes and colours and digits in the fourth graders and a maximum of .66 between the tests of shapes and colours and colours also in the fourth graders. In addition, there is a clear superiority of the RAN digit test in terms of the magnitude of the associations with the different dimensions of reading and spelling (e.g., digit test correlations with reading are mostly superior to.50, while colours test correlations with reading are mostly inferior to .40 ).

\section{Regression Analysis}

To determine the effect of rapid naming on reading and spelling, several hierarchical regression analyses were done. The dependent variables were those related to accuracy and fluency in the reading of words, pseudowords and text as well as those related to accuracy and fluency in the spelling of words. Therefore, none of the variables related to the spelling of pseudowords was selected be- 
cause these have revealed weak associations with rapid naming.

To compare the influence of both RAN tests and the RAS test, each was considered separately. They entered the equation at step 1, or at step 2 or step 3 after controlling for other variables. The results are shown in tables 3 and 4 .
With regard to reading, table 3 shows that rapid naming explains significant percentages of the variance of any one of the reading dimensions under analysis. Nonetheless, and within each of the dimensions and the school grades, the percentages related to fluency are always higher than those related to accuracy. When phonological awareness is

Table 3

Hierarchical regression analyses for reading

\begin{tabular}{|c|c|c|c|c|c|c|c|c|c|c|c|c|}
\hline & \multicolumn{2}{|c|}{$\begin{array}{l}\text { Word } \mathrm{R}^{\mathrm{a}} \text {. } \\
\text { Accuracy }\end{array}$} & \multicolumn{2}{|c|}{$\begin{array}{l}\text { Word Ra. } \\
\text { Fluency }\end{array}$} & \multicolumn{2}{|c|}{$\begin{array}{l}\text { Pseudoword } \\
\mathrm{R}^{\mathrm{a}} \text {. Accuracy }\end{array}$} & \multicolumn{2}{|c|}{$\begin{array}{l}\text { Pseudoword } \mathrm{R}^{\mathrm{a}} \text {. } \\
\text { Fluency }\end{array}$} & \multicolumn{2}{|c|}{$\begin{array}{l}\text { Text Ra } \\
\text { Accuracy }\end{array}$} & \multicolumn{2}{|c|}{ Text $\mathrm{R}^{\mathrm{a}}$. Fluency } \\
\hline & \multicolumn{12}{|c|}{$3^{\text {rd }}$ Grade } \\
\hline & $\mathrm{R}^{2}$ & $\Delta R^{2}$ & $\mathrm{R}^{2}$ & $\Delta R^{2}$ & $\mathrm{R}^{2}$ & $\Delta R^{2}$ & $\mathrm{R}^{2}$ & $\Delta R^{2}$ & $\mathrm{R}^{2}$ & $\Delta R^{2}$ & $\mathrm{R}^{2}$ & $\Delta R^{2}$ \\
\hline \multicolumn{13}{|c|}{ Step } \\
\hline $1-\mathrm{PA}$ & $.50 * *$ & & $.14 * *$ & & $.34 * *$ & & $.20 * *$ & & $.15^{* *}$ & & $.11^{*}$ & \\
\hline 2- RN Digits & $.59 * *$ & $.08 * *$ & $.39 * *$ & $.25^{* *}$ & $.38^{* *}$ & .04 & $.41 * *$ & $.21^{* *}$ & $.48^{* *}$ & $.33 * *$ & $.46^{* *}$ & $.35^{* *}$ \\
\hline 2- $\mathrm{RN} \mathrm{SC}^{\mathrm{b}}$ & $.52 * *$ & .02 & $.23 * *$ & $.09 *$ & $.42 * *$ & $.08 * *$ & $.29 * *$ & $.09 *$ & $.36^{* *}$ & $.21 * *$ & $.30 * *$ & $.19 * *$ \\
\hline 2- RN Colors & $.54 * *$ & $.04 *$ & $.29 * *$ & $.15^{* *}$ & $.36^{* *}$ & .02 & $.30 * *$ & $.10^{* *}$ & $.33^{* *}$ & $.18^{* *}$ & $.32 * *$ & $.22 * *$ \\
\hline 1- RN Digits & $.27 * *$ & & $.36^{* *}$ & & $.16^{* *}$ & & $.34 * *$ & & $.44^{* *}$ & & $.45^{* *}$ & \\
\hline 2- PA & $.59 * *$ & $.32 * *$ & $.39 * *$ & .03 & $.38 * *$ & $.22 * *$ & $.41 * *$ & $.07 *$ & $.46^{* *}$ & .02 & $.46^{* *}$ & .01 \\
\hline 1- RN SC & .06 & & $.13^{* *}$ & & $.15^{* *}$ & & $.14^{* *}$ & & $.27 * *$ & & $.23 * *$ & \\
\hline 2- PA & $.52 * *$ & $.46^{* *}$ & $.23 * *$ & $.11^{*}$ & $.42 * *$ & $.27 * *$ & $.29 * *$ & $.15^{*}$ & $.36^{* *}$ & $.09 *$ & $.30 * *$ & $.06 *$ \\
\hline 1- RN Colors & .02 & & $.12^{*}$ & & .01 & & $.08 *$ & & $.16^{* *}$ & & $.19 * *$ & \\
\hline \multirow[t]{2}{*}{ 2- PA } & $.54 * *$ & $.52 * *$ & $.29 * *$ & $.17^{* *}$ & $.36^{* *}$ & $.35^{* *}$ & $.30 * *$ & $.22 * *$ & $.33 * *$ & $.17 * *$ & $.32 * *$ & $.13^{* *}$ \\
\hline & \multicolumn{12}{|c|}{$4^{\text {th }}$ Grade } \\
\hline $1-\mathrm{PA}$ & $.38^{* *}$ & & $.18^{* *}$ & & $.18^{* *}$ & & $.15^{* *}$ & & .01 & & $.14^{* *}$ & \\
\hline 2- RN Digits & $.40^{* *}$ & .01 & $.35^{* *}$ & $.17 * *$ & $.26^{* *}$ & $.08^{*}$ & $.33 * *$ & $.18^{* *}$ & $.15^{*}$ & $.14 * *$ & $.37 * *$ & $.24 * *$ \\
\hline 2- $\mathrm{RN} \mathrm{SC}^{\mathrm{b}}$ & $.47 * *$ & $.08^{* *}$ & $.27 * *$ & $.09 *$ & $.18^{* *}$ & .00 & $.18^{* *}$ & .03 & .06 & .05 & $.24 * *$ & $.11^{*}$ \\
\hline 2- RN Colors & $.46^{* *}$ & $.07 *$ & $.26^{* *}$ & $.09 *$ & $.18^{* *}$ & .00 & $.21 * *$ & .06 & .03 & .02 & $.30 * *$ & $.16^{* *}$ \\
\hline 1- RN Digits & $.09 *$ & & $.27 * *$ & & $.16^{* *}$ & & $.27 * *$ & & $.15^{* *}$ & & $.33 * *$ & \\
\hline 2- PA & $.40^{* *}$ & $.31 * *$ & $.35^{* *}$ & $.08^{*}$ & $.26^{* *}$ & $.10^{*}$ & $.33 * *$ & $.06^{*}$ & $.15^{* *}$ & .00 & $.37 * *$ & .04 \\
\hline $1-\mathrm{RN} \mathrm{SC}^{\mathrm{b}}$ & $.11^{*}$ & & $.11^{*}$ & & .01 & & .04 & & .05 & & $.13^{*}$ & \\
\hline 2- PA & $.47 * *$ & $.45^{* *}$ & $.27 * *$ & $.16^{*}$ & $.18^{* *}$ & $.18^{* *}$ & $.18^{* *}$ & $.14^{* *}$ & .06 & .01 & $.24 * *$ & $.11^{* *}$ \\
\hline 1- RN Colors & $.10^{*}$ & & $.11^{*}$ & & .00 & & $.08^{*}$ & & .03 & & $.19 * *$ & \\
\hline 2- PA & $.43 * *$ & $.35^{* *}$ & $.26^{* *}$ & $.16^{*}$ & $.18^{* *}$ & $.18^{* *}$ & $.21 * *$ & $.13^{* *}$ & .03 & .00 & $.30 * *$ & $.11^{* *}$ \\
\hline
\end{tabular}

${ }^{\mathrm{a}} \mathrm{R} .=$ Reading ${ }^{\mathrm{b}} \mathrm{RN} \mathrm{SC}=$ Rapid Naming Shapes and Colors

$* \mathrm{p}<.05 * * \mathrm{p}<.01$ 
Table 4

Hierarchical regression analyses for spelling

\begin{tabular}{|c|c|c|c|c|c|c|c|c|}
\hline & Word & curacy & Word & uency & Word & curacy & Word & dency \\
\hline & & & & & & & & \\
\hline & $\mathrm{R}^{2}$ & $\Delta R^{2}$ & $\mathrm{R}^{2}$ & $\Delta R^{2}$ & $\mathrm{R}^{2}$ & $\Delta R^{2}$ & $\mathrm{R}^{2}$ & $\Delta R^{2}$ \\
\hline & & & & & & & & \\
\hline 1- PA & $.15 * *$ & & $.11^{* *}$ & & $.20 * *$ & & $.08^{*}$ & \\
\hline 2- Handwriting & $.29 * *$ & $.14 * *$ & $.45 * *$ & $.34 * *$ & $.24 * *$ & .04 & $.13^{*}$ & .05 \\
\hline 3- RN Digits & $.33 * *$ & .04 & $.49 *$ & $.04 *$ & $.25 * *$ & .01 & $.17^{*}$ & .04 \\
\hline 3- $\mathrm{RN} \mathrm{SC}^{\mathrm{b}}$ & $.34 * *$ & .05 & $.51 * *$ & $.05^{*}$ & $.28 * *$ & .04 & $.20^{*}$ & $.07 *$ \\
\hline 3- RN Colors & $.31 * *$ & .02 & $.52 * *$ & $.07 *$ & $.28 * *$ & .04 & $.21 *$ & $.08 *$ \\
\hline 1- Handwriting & $.23 * *$ & & $.44 * *$ & & .00 & & $.10^{*}$ & \\
\hline 2- PA & $.29 * *$ & $.06^{*}$ & $.46^{* *}$ & .02 & $.24 * *$ & $.24 * *$ & $.13 *$ & .03 \\
\hline 3- RN Digits & $.33 * *$ & .04 & $.50 * *$ & $.04 *$ & $.25 * *$ & .01 & $.17^{*}$ & .04 \\
\hline 3-RN SC & $.34 * *$ & .05 & $.51 * *$ & $.05^{*}$ & $.28 * *$ & .04 & $.21^{*}$ & $.07 *$ \\
\hline 3- RN Colors & $.31 * *$ & .02 & $.52 * *$ & $.06 * *$ & $.28 * *$ & .04 & $.21^{*}$ & $.08^{*}$ \\
\hline 1- RN Digits & $.23 * *$ & & $.32 * *$ & & .02 & & $.12 *$ & . \\
\hline 2- PA & $.28 * *$ & $.05^{*}$ & $.34 * *$ & .02 & $.20 * *$ & $.18^{* *}$ & $.16^{*}$ & .04 \\
\hline 3- Handwriting & $.33 * *$ & .05 & $.50 * *$ & $.16^{* *}$ & $.25 * *$ & .05 & $.17^{*}$ & .01 \\
\hline $1-\mathrm{RN} \mathrm{SC}^{\mathrm{b}}$ & $.13 * *$ & & $.18 * *$ & & .05 & & $.10^{*}$ & \\
\hline 2- PA & $.24 * *$ & $.11 * *$ & $.25 * *$ & $.07 *$ & $.23 * *$ & $.18 * *$ & $.17 *$ & $.07 *$ \\
\hline 3- Handwriting & $.34 * *$ & $.09 *$ & $.51 * *$ & $.26^{* *}$ & $.28 * *$ & .05 & $.21 *$ & .04 \\
\hline 1- RN Colors & .05 & & $.16^{* *}$ & & .06 & & $.09^{*}$ & \\
\hline 2- PA & $.22 * *$ & $.17 * *$ & $.30 * *$ & $.14^{* *}$ & $.24 * *$ & $.18^{* *}$ & $.16^{*}$ & $.07 *$ \\
\hline 3- Handwriting & $.31 * *$ & $.09 *$ & $.52 * *$ & $.22 * *$ & $.28 * *$ & .04 & $.21 * *$ & .05 \\
\hline
\end{tabular}

${ }^{\mathrm{a}} \mathrm{S}=$ Spelling ${ }^{\mathrm{b}} \mathrm{RN} \mathrm{SC}=$ Rapid Naming Shapes and Colors

$* \mathrm{p}<.05 * * \mathrm{p}<.01$

controlled for, the highest values occur in fluency in text reading, in which the RAN digit test explains, respectively, $35 \%$ and $24 \%$ of the variance in the third and fourth graders. Equally important are the values registered in the fluency of reading words and pseudowords, highlighting, once again, those related to the digit test. In addition, percentages that are significant but lower than the previous ones are found in the accuracy in reading words and pseudowords. Except for minor exceptions, the predictive power of the RAN digit test supersedes any of the other two tests of rapid naming. The important role of phonological awareness regarding accuracy in reading words and pseudowords must also be underlined because it explains most of the variance.

With regard to spelling, we notice that rapid naming, after controlling for the influence of phonological awareness and handwriting fluency, is a predictor not of accuracy but of fluency. In fact, it 
explains small but significant percentages of variance (between $4 \%$ and $8 \%$ ), which appear to be similar regardless of the rapid naming test. Regarding spelling fluency, the important role played by handwriting, particularly in the third grade, must also be highlighted.

\section{Discussion}

This study contributes to the growth of the empirical evidence on the influence of rapid naming in learning to read and write European Portuguese, demonstrating that this influence extends to normally achieving children in the third and fourth grades.

As far as reading is concerned, we emphasise the role of rapid naming on accuracy and fluency in reading words, pseudowords and a text, which is, however, more important in terms of fluency than accuracy. Moreover, within each of these dimensions, the effect of rapid naming is greater on a text than on words and pseudowords and especially on fluency in reading a text. Regarding these data, we start by highlighting the relevance of considering different reading materials and different reading dimensions because discrepancies in the current empirical evidence might originate at this level. In fact, there are several studies about rapid naming and reading that focus on only one reading dimension (e.g., Araújo et al., 2010; Georgiou et al., 2008; Nikolopoulos et al., 2006; Smythe et al., 2008) or that use just one reading material, namely words (e.g., Araújo et al., 2010; Georgiou et al., 2008; Nikolopoulos et al., 2006; Protopapas et al., 2013; Smythe et al., 2008; Ziegler et al., 2010). However, reading words is distinct from reading pseudowords, and reading single words without a context is distinct from reading words in a textual context. Specifically, reading isolated words or pseudowords involves identification processes, whereas reading a text involves an orchestration of processes of identification and comprehension (Jenkins, Fuchs, van den Broek, Espin, \& Deno, 2003). On the other hand, it is consensual that reading involves multiple dimensions (decoding, fluency and comprehension), and therefore, the analysis of the effect of any variable must address this diversity.

In this context, the present study confirms the predictive power of rapid naming regarding fluency in reading, measured in terms of accuracy and speed (Babayiğit \& Stainthorp, 2011; Georgiou et al., 2008, 2011; Papadopoulos et al., 2009; van den Bos et al., 2002). As we have mentioned, equating fluency in terms of accuracy and speed is inevitably incomplete because it does not assess, in the case of reading of a text, the prosody and flexibility of the reading pace depending on the text complexity (Kuhn et al., 2010). Nonetheless, equating fluency in terms of accuracy and speed, as done in this study, better reflects its essence than only considering speed, as done in other studies (e.g., Di Filippo et al., 2005; Ding et al., 2010; Moll et al., 2009; Nikolopoulos et al., 2006; Ziegler et al., 2010).

The fact that the predictive power of rapid naming is particularly important in terms of fluency may be the result of the multicomponent and automatic nature of both; i.e., both involve the simultaneous, rapid and effortless use of various processes. Thus, fluency requires accuracy and automaticity in sublexical and lexical processes, whereas rapid naming requires the establishment of automatic connections between linguistic and perceptive processes (Norton \& Wolf, 2012) and therefore represents a microcosm of reading. In addition, the particularly important role of rapid naming in text reading fluency may be because the rapid processing of serial visual stimuli has a closer resemblance to the sequential and parallel processing of words inherent to the reading of a text. That is, both involve a cascade processing or a simultaneous and parallel processing of multiple items in such a way that an item is phonologically processed while the previous item is articulated and the next item is visually recognised (Protopapas et al., 2013).

Regarding spelling, there was also an association and a specific influence of rapid naming in 
word spelling fluency. As it has been mentioned regarding reading, these data reveal the importance of considering the dimensions of accuracy and fluency in spelling, the latter being equated, similarly to reading, in terms of accuracy and speed. In fact, the analysis of rapid naming's relationships with writing have focused on spelling accuracy (e.g., Babayiğit \& Stainthorp, 2011; Ding et al., 2010; Georgiou et al., 2011; Savage et al., 2008), ignoring spelling fluency and only occasionally considering fluency in composition (Albuquerque, 2012; Babayiğit \& Stainthorp, 2010, 2011; Yan et al., 2012). Therefore, this study adds to the available empirical data that already indicated a favourable influence of rapid naming on fluency in composition (Albuquerque, 2012; Babayiğit \& Stainthorp, 2011) with evidence related to spelling fluency. Furthermore, the specific influence of rapid naming was observed after controlling for the effect of two important variables (phonological awareness and handwriting) that have not been addressed simultaneously in previous research. Thus, the results obtained are innovative both in terms of spelling fluency, and of the variables controlled.

Similar to what was observed by Yan et al. (2012), the rapid naming of digits reveals moderate correlations with handwriting fluency in third and fourth graders. However, the same is not true with the rapid naming of colours and shapes and colours, which have low correlations with handwriting fluency. This differential pattern of associations lies in the characteristics of each test because rapid naming of digits is more automatic and less demanding in terms of the language and cognitive processes involved than either of the other two tests (Närhi et al., 2005; Wiig et al., 2000). In turn, the handwriting fluency also calls for the automaticity of basic processes, especially as children progress in schooling. Nevertheless, the fact that the correlations are moderate and restricted to the RAN digit test refutes the possibility that rapid naming assess only the automaticity with which tasks are performed.
Another alternative explanation of the role of rapid naming indicates that it may be just a processing speed measure (Kail, Hall, \& Caskey, 1999). This explanation was developed for the link between rapid naming and reading, and proposed that as information processing skills increase through development so will reading ability. Thus, the relationship between rapid naming and reading would be explained by the fact that both are influenced by processing speed. Although some data indicated that processing speed and rapid naming tasks were correlated (Kail et al., 1999), other data showed that the correlations were weak and non significant (Di Filippo et al., 2005). Further, some studies directly tested the processing speed explanation of rapid naming and found that after controlling processing speed, rapid naming still significantly contributed to the prediction of reading ability $(\mathrm{Cu}-$ tting \& Denckla, 2001; Powell, Stainthorp, Stuart, Garwood, \& Quinlan, 2007; Vaessen \& Blomert, 2010). The present study addresses speed by considering handwriting fluency, that is, speed is addressed as directly involved in writing. Therefore, this study distinguishes itself from the studies just mentioned, that focused on reading. Under these circumstances, the predictive power of rapid naming regarding spelling remained after the effect of handwriting fluency was controlled for. This fact, together with the demonstration that rapid naming also explains variance in reading accuracy, is inconsistent with the possibility that rapid naming is a simple measure of processing speed.

Regarding the comparison of the RAN digit and colour tests and the RAS test of shapes and colours, the results obtained in this study emphasise that these instruments do not entirely evaluate the same: we refer to the moderate correlations between them and the superiority of the digit test in terms of the associations with handwriting fluency and reading. This superiority may be rooted in the reasons stated above, especially the automatic nature of digit naming. For example, in European Portuguese digits have names with a smaller number of syllables 
(1 or 2$)$ than colours (2, 3 or 4 syllables) or shapes (3 or 4 syllables); therefore, in the case of digits, it will be easy to establish associations between visual symbols and their respective phonological representations. Additionally, the automaticity of the digit matching is more compatible with the successive processing of stimuli inherent to an accurate and fast decoding of words or a text in the third and fourth grades of schooling (Protopapas et al., 2013).

On the contrary, in spelling, there was no predominance of the predictive power of one of the rapid naming tests over others. In this regard, we must also emphasise that the influence of rapid naming is less important in the spelling than in the reading of European Portuguese, as has been observed in other languages (for example, English - Cardoso-Martins \& Pennington, 2004; German-Landerl \& Wimmer, 2008; Moll et al., 2009; Dutch-Vaessen et al., 2009; and Turkish-Babayiğit \& Stainthorp, 2010, 2011). This more modest influence of rapid naming may be the effect of multiple factors, that would also be involved in the more homogeneous influence exerted by different tests of rapid naming. Thus, first, learning to spell is very complex and involves different cognitive, phonological, orthographic (or visual) and morphosyntactic processes. Spelling acquisition also requires both reflective and automatic processing (Berninger et al., 2006). Therefore, there can be a less clear overlapping of rapid naming with spelling than with reading. Second, spelling was assessed through the dictation of words and pseudowords, that is to say, through the production of graphemes that correspond to phonemes and not through tasks of orthographic choice, in which the child analyses words with different spelling patterns and chooses one. And rapid naming has proven to be more related to the specific orthographic knowledge inherent in this latter type of assessment (Sunseth \& Bowers, 2002). Third, learning to spell is influenced by the orthographic consistency of the language, which in the case of European Portuguese, is more pronounced in reading than in spelling; that is to say, it is more difficult to learn to spell. Furthermore, learning to spell tends to take place over a long period of time (Berninger \& Swanson, 1994), which implies that automaticity may be more difficult to establish and the role of rapid naming harder to circumscribe.

Given the above, it would be important to analyse the relationship between rapid naming and writing during the subsequent years of schooling and to consider other tasks and dimensions of writing with an emphasis on fluency in composition. There is also a need to adopt a broader temporal perspective for reading and to constitute a larger sample than the one used in the present study.

\section{References}

Albuquerque, C. P. (2012). Rapid naming contributions to reading and writing acquisition of European Portuguese. Reading and Writing: An Interdisciplinary Journal, 25, 775-797. doi: 10. 1007/s11145-011-9299-6.

Araújo, S., Pacheco, A., Faísca, L., \& Petersson, K. M. (2010). Visual rapid naming and phonological abilities: Different subtypes in dyslexic children. International Journal of Psychology, 45, 443-452. doi: 10.1080/00207594.2010.499949

Bacelar do Nascimento, M. F., Casteleiro, J. M., Marques, M. L. G., Barreto, F., Amaro, R., \& Veloso, R. (2005). Corlex: Léxico multifuncional computorizado do Português contemporâneo [lmcpc_dec.txt] (Computorized multifunctional lexic of contemporary Portuguese). Centro de Linguística da Universidade de Lisboa. Recuperado de http://www.clul.ul.pt/sectores/linguistica_de_corpus/projecto_lmcpc.php

Babayiğit, S. \& Stainthorp, R. (2010). Component processes of early reading, spelling, and narrative writing skills in Turkish: A longitudinal study. Reading and Writing: An Interdisciplinary Journal, 23, 539-568. doi: 10.1007/ s11145-009-9173-y 
Babayiğit, S. \& Stainthorp, R. (2011). Modeling the relationships between cognitive-linguistic skills and literacy skills: New insights from a transparent orthography. Journal of Educational Psychology, 103(1), 169-189. doi: 10.1037/ a0021671

Berninger, V. W., Abbott, R. D., Jones, J., Wolf, B. J., Gould, L., Anderson-Youngstrom, M., Shimada, S., \& Apel, K. (2006). Early development of language by hand: Composing, reading, listening, and speaking connections; Three letter-writing modes; and Fast mapping in spelling. Developmental Neuropsychology, 29(1), 61-92. doi: 10. 1207/s15326942dn2901-5

Berninger, V. W. \& Rutberg, J. (1992). Relationship of finger function to beginning writing: Application to diagnosis of writing difficulties. Developmental Medicine and Child Neurology, 34, 198-215.

Berninger, V. W. \& Swanson, H. L. (1994). Modifying Hayes and Flower's model of skilled writing to explain beginning and developing writing. In E. C. Butterfield \& J. S. Carlson (Eds.), Advances in cognition and educational practice (Vol. 2, pp. 57-81). Greenwich: JAI Press.

Borgwaldt, S. R., Hellwig, F. M., \& De Groot, A. M. B. (2005). Onset entropy matters - Letter to phoneme mappings in seven languages. Reading and Writing: An Interdisciplinary Journal, 18 , 211-229. doi: 10. 1007/s11145-005-3001-9

Bowers, P. G. \& Swanson, L. B. (1991). Naming speed deficits in reading disability: Multiple measures of a singular process. Journal of Experimental Child Psychology, 51, 195-219.

Cardoso-Martins, C., Corrêa, M. F., \& Magalhães, L. F. S. (2010). Dificuldade específica de aprendizagem da leitura e escrita (Specific reading and writing disability). In L. F. Malloy-Diniz, D. Fuentes, P. Mattos, \& N. Abreu (Org.), Avaliação neuropsicológica (pp. 133-149). Porto Alegre: Artmed.

Cardoso-Martins, C. \& Pennington, F. B. (2004). The relationship between phoneme awareness and rapid serial naming skills and literacy acquisition: The role of developmental period and reading ability. Scientific Studies of Reading, 8(1), 27-52. doi: 10.1207/s1532799xssr0801_3

Carvalho, A. (2010). Teste de avaliação da fluência e precisão da leitura - O Rei (Test of reading accuracy and fluency - The King). Vila Nova de Gaia: Edipsico.

Cutting, L. E. \& Denckla, M. B. (2001). The relationship of rapid serial naming and word reading in normally developing readers: An exploratory model. Reading and Writing: An Interdisciplinary Journal, 14, 673-705.

de Jong, P. F., \& van der Leij, A. (2002). Effects of phonological abilities and linguistic comprehension on the development of reading. Scientific Studies of Reading, 6(1), 51-77.

Di Filippo, G., Brizzolara, D., Chilosi, A., De Luca, M., Judica, A., Pecini, C., Spinelli, D., \& Zocolotti, P. (2005). Rapid naming, not cancellation speed or articulation rate, predicts reading in an orthographically regular language (italian). Child Neuropsychology, 11, 349-361. doi: 10.1080/09297040490916947

Ding, Y., Richman, L. C., Yang, L.-Y., \& Guo, J.-P. (2010). Rapid automatized naming and immediate memory functions in Chinese mandarin-speaking elementary readers. Journal of Learning Disabilities, 43, 48-61. doi: 10.1177/0022219409345016

Fayol, M. \& Miret, A. (2005). Écrire, orthographier et rédiger des textes. Psychologie Française, 50, 391-402. doi: 10.1016/j.psfr.2005.05.008

Festas, I.,. Leitão, J. A., Formosinho, M. D., Albuquerque, C., Vilar, M., Martins, C., et al. (2006). PAL-PORT - Uma bateria de avaliação psicolinguística das afasias e de outras perturbações da linguagem para a população portuguesa (A psycholinguistic battery for the assessment of aphasias and other language disorders in the Portuguese population). In C. Machado, L. Almeida, A. Guisande, M. Gonçalves, \& V. Ramalho (Eds.), XI Conferência Internacional 
Avaliação Psicológica: Formas e Contextos (pp. 719-729). Braga: Ed. Psiquilibrios.

Georgiou, G. K., Hirvonen, R., Liao, C.-H., Manolitsis, G., Parrila, R., \& Nurmi, J.-E. (2011). The role of achievement strategies on literacy acquisition across languages. Contemporary Educational Psychology, 36, 130-141. doi: 10.1016/j. cedpsych.2011.01.001

Georgiou, G. K., Parrila, R., \& Liao, C.-H. (2008). Rapid naming speed and reading across languages that vary in orthographic consistency. Reading and Writing: An Interdisciplinary Journal, 21, 885-903. doi: 10.1007/s11145-007-9096-4

Graham, S., Berninger, V. W., Abbott, R. D., Abbott, S. P., \& Whitaker, D. (1997). Role of mechanics in composing of elementary school students: A new methodological approach. Journal of Educational Psychology, 89(1), 170-182.

Hammill, D. D., Mather, N., Allen, E. A., \& Roberts, R. (2002). Using semantics, grammar, phonology, and rapid naming tasks to predict word identification. Journal of Learning Disabilities, 35, 121-136.

Jenkins, J. R., Fuchs, L. S., van den Broek, P., Espin, C., \& Deno, S. L. (2003). Accuracy and fluency in list and context reading of skilled and RD groups: Absolute and relative performance levels. Learning Disabilities Research \& Practice, 18(4), 237-245.

Justi, C. N. G. \& Roazzi, A. (2012). A contribuição de variáveis cognitivas para a leitura e a escrita no Português Brasileiro. Psicologia: Reflexão e Crítica, 25(3), 605-614.

Kail, R., Hall, L. K., \& Caskey, B. J. (1999). Processing speed, exposure to print, and naming speed. Applied Psycholinguistics, 20, 303-314.

Kuhn, M. R., Schwanenflugel, P. J., \& Meisinger, E. B. (2010). Aligning theory and assessment of reading fluency: Automaticity, prosody, and definitions of fluency. Reading Research Quarterly, 45(2), 230-251. doi: doi.org/10.1598/ RRQ.45.2.4
Landerl, K. \& Wimmer, H. (2008). Development of word reading fluency and spelling in a consistent orthography: An 8-year follow-up. Journal of Educational Psychology, 100(1), 150-161. doi: 10.1037/0022-06663.100.1.150

Manis, F. R., Doi, L. M., \& Bhadha, B. (2000). Naming speed, phonological awareness, and ortographic knowledge in second graders. Journal of Learning Disabilities, 33, 325-333.

Moll, K., Fussenegger, B., Willburger, E., \& Landerl, K. (2009). RAN is not a measure of orthographic processing. Scientific Studies of Reading, 13(1), 1-25. doi: 10.1080/10888430802631684

Närhi, V., Ahonen, T., Aro, M., Leppäsaari, T., Korhonen, T., Tolvanen, A., \& Lyytinen, H. (2005). Rapid serial naming: Relations between different stimuli and neuropsychological factors. Brain and Language, 92, 45-57. doi: 10.1016/j. bandl.2004.05.004

Nikolopoulos, D., Goulandris, N., Hulme, C., \& Snowling, M. J. (2006). The cognitive bases of learning to read and spell in Greek: Evidence form a longitudinal study. Journal of Experimental Child Psychology, 94, 1-17. doi: 10.1016/j.jecp.2005.11.006

Norton, E. S. \& Wolf, M. (2012). Rapid automatized naming (RAN) and reading fluency: Implications for understanding and treatment of reading disabilities. Annual Review of Psychology, 63, 427-452. doi: 10.1146/annurev-psych-120710-100431

Olive, T., Favart, M., Beauvais, C., \& Beauvais, L. (2009). Children's cognitive effort and fluency in writing: Effects of genre and of handwriting automatisation. Learning and Instruction, 19, 290-308.

Papadopoulos, T. C., Georgiou, G. K., \& Kendeou, P. (2009). Investigating the double-deficit hypothesis in Greek. Findings from a longitudinal study. Journal of Learning Disabilities, 42(6), 528-547. doi: 10.1177/0022219409338745

Powell, D., Stainthorp, R., Stuart, M., Garwood, H., \& Quinlan, P. (2007). An experimental compari- 
son between rival theories of rapid automatized naming performance and its relationship to reading. Journal of Experimental Child Psychology, 98, 46-68. doi: 10.1016/j.jecp.2007.04.003 Protopapas, A., Altani, A., \& Georgiou, G. K. (2013). Development of serial processing in reading and rapid naming. Journal of Experimental Child Psychology, 116, 914-929. doi: 10.1016/j.jecp.2013.08. 004

Puolakanaho, A., Ahonen, T., Aro, M., Eklund, K., Leppanen, P. H. T., Poikkeus, A.-M., \& Lyytinen, H. (2008). Developmental links of early phonological and language skills to second grade reading outcomes. Strong to accuracy but only minor to fluency. Journal of Learning Disabilities, 41,353-379. doi: 10.1177/0022219407311747

Savage, R. S., Frederickson, N., Goodwin, R., Patni, U., Smith, N., \& Tuersley, L. (2005). Relationships among rapid digit naming, phonological processing, motor automaticity and speech perception in poor, average, and good readers and spellers. Journal of Learning Disabilities, $38,12-28$.

Savage, R., Pillay, V., \& Melidona, S. (2008). Rapid serial naming is a unique predictor of spelling in children. Journal of Learning Disabilities, 41,235-250. doi: 10.1177/0022219408315814

Seymour, P. H. K., Aro, M., \& Erskine, J. M. (2003).

Foundation literacy acquisition in European orthographies. British Journal of Psychology, 94, 143-174

Simões, M., Albuquerque, C., Pinho, S., Pereira, M., Seabra-Santos, M., Alberto, I., Lopes, A., Vilar, M., \& Gaspar, F. (2008). Relatório do Projecto adaptação e aferição de testes neuropsicológicos: Estudos psicométricos (Report of the Project Adaptation and normative data of neuropsychological tests: Psychometric studies) (SAPIENS/POCTI/35410/2000; 2000-2007). Coimbra: Faculdade de Psicologia e de Ciências da Educação da Universidade de Coimbra.

Smythe, I., Everatt, J., Al-Menaye, N., He, X., Capellini, S., Gyarmathy, E., \& Siegel, L. S. (2008).
Predictors of word-level literacy amongst grade 3 children in five diverse languages. Dyslexia, 14, 170-187. doi: 10.1002/dys.369

Stainthorp, R., Powell, D., \& Stuart, M. (2013). The relationship between rapid naming and word spelling in English. Journal of Research in Reading, 36, 371-388. doi: 10.1111/jrir.12002

Sucena, A., Castro, S. L., \& Seymour, P. (2009). Developmental dyslexia in an orthography of intermediate depth: the case of European Portuguese. Reading and Writing: An Interdisciplinary Journal, 22, 791-810. doi: 10.1007/ s11145-008-9156-4

Sunseth, K. \& Bowers, P. G. (2002). Rapid naming and phonemic awareness: Contributions to reading, spelling and orthographic knowledge. Scientific Studies of Reading, 6(4), 401-429. doi: 10.1207/s1532799xssr0604_05

Vaessen, A. \& Blomert, B. (2010). Long-term cognitive dynamics of fluent reading development. Journal of Experimental Child Psychology, 105, 213-231. doi: 10.1016/j.jecp.2009.11. 005

Vaessen, A., Gerretsen, P., \& Blomert, L. (2009). Naming problems do not reflect a second independent core deficit in dyslexia: Double deficits explored. Journal of Experimental Child Psychology, 103, 202-221. doi: 10.1016/j.jecp.2008.12.004

van den Bos, K. P., Zijlstra, J. H., \& Spelberg, H. C. 1. (2002). Life-span data on continuous-naming speeds of numbers, letters, colors, and pictured objects, and word-reading speed. Scientific Studies of Reading, 6(1), 25-49.

Wiig, E. H., Zureich, P., \& Chan, N. H. (2000). A clinical rationale for assessing rapid automatized naming in children with language disorders. Journal of Learning Disabilities, 33, 359-372.

Wilcox, R. R. (2005). Introduction to robust estimation and hypothesis testing ( $\left.2^{\text {nd }} e d.\right)$. San Diego: Elsevier Academic Press.

Yan, C. M. W., McBride-Chang, C., Wagner, R. K., Zhang, J., Wong, A. M. Y., \& Shu, H. (2012). Writing quality in Chinese children: speed and 
fluency matter. Reading and Writing: An Interdisciplinary Journal, 25, 1 499-1 521. doi: 10. 1007/s11145-011-9330-y

Ziegler, J. C., Bertrand, D., Tóth, D., Csépe, V., Reis, A., Faísca, L., \& Blomert, L. (2010). Orthographic depth and its impact on universal predictors of reading: A cross language investigation. Psychological Science, 21, 551-559. doi: 10.1177/0956797610363406 